\title{
Immunoassay of tear lysozyme in acute adenovirus conjunctivitis
}

\author{
A K GUPTA, G S SARIN, P A LAMBA, AND P D'SOUZA \\ From the Guru Nanak Eye Centre and Maulana Azad Medical College, New Delhi, India
}

SUMMARY The tear lysozyme levels were measured by immunoassay in 92 healthy subjects and 98 patients with acute adenovirus conjunctivitis. They were found to be significantly decreased during the acute phase of the disease. The extent of this decline in the tear lysozyme level was correlated with increased severity of disease. There was no significant difference in the tear lysozyme level in viral isolation-positive and isolation-negative patients. The tear lysozyme level showed return to normal levels with clinical improvement.

Lysozyme is an easily measurable component of human tears and is of diagnostic value in certain ocular diseases.' Tears deficient in lysozyme have been described in Sjögren's syndrome, ${ }^{23}$ keratoconjunctivitis sicca, ${ }^{+7}$ smog irritated eyes, ${ }^{8}$ herpes sim-

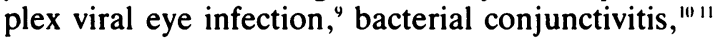
trachoma, ${ }^{12}$ lepromatous leprosy, ${ }_{13}^{13}$ corneal ulcer, ${ }^{1+15}$ and protein calorie malnutrition. ${ }^{16}$

The tear immunoglobulin, ${ }^{17}$ serum immunoglobulin, ${ }^{17}$ and complement component ${ }^{18}$ levels have been estimated by us in patients with acute adenovirus conjunctivitis. However, tear lysozyme levels have not been studied. Here we report our observations on tear lysozyme levels in patients suffering from adenovirus conjunctivitis in the acute and remission stages. The findings on adenovirus culture and serological titres have been described elsewhere. ${ }^{19}$

\section{Material and methods}

The study was carried out among 92 healthy subjects and 98 patients with acute adenovirus conjunctivitis attending the outpatient department of Guru Nanak Eye Centre, New Delhi. The control group comprised healthy subjects who had no evidence of ocular or systemic disease and who attended the Eye Centre during the same period mainly for the purpose of refraction. In the control group were 48 males and 44 females with a mean age of 34.5 (SD 16.7) years (range 8 to 63 years) and the diseased group comprised 80 males and 18 females with mean age of 28.3 (SD 12.9) years (range 5 to 63 years). The

Correspondence to Dr A K Gupta, VI/6, Maulana Azad Medical College Campus, Kotla Road, New Delhi-110 002, India. diagnosis of acute adenovirus conjunctivitis was established by detailed clinical examination including slit-lamp biomicroscopy, bacterial culture, viral culture, and specific serological studies. The patients were subgrouped as mild, moderate, and severe according to the intensity of chemosis and congestion. All patients from whom pathogenic bacteria were isolated from conjunctival swabs were subsequently excluded from the present study. Adenovirus types 2,7 , and 8 could be cultured only from 30 out of 98 patients, and the findings are reported elsewhere. ${ }^{19}$

Tear samples were also collected for lysozyme level analysis from 56 patients with adenovirus conjunctivitis during the stage of remission when there was no clinical evidence of the disease.

Stimulated tear samples $(100$ to $200 \mu \mathrm{l})$ were collected by the method described previously ${ }^{20}$ and stored at $-20^{\circ} \mathrm{C}$ until assayed. The lysozyme level in tear samples was quantified by a single radial immunodiffusion technique ${ }^{21}$ as modified and described previously. ${ }^{22}$ Monospecific rabbit antihuman lysozyme serum was obtained commercially from the Behring Institute, West Germany. The reference standard was obtained from Kallestad, USA. The level of lysozyme in tears was calculated from the calibration curve constructed by incorporating three known concentrations of reference standard for every set of lysozyme determinations. The results were statistically analysed by Student's $t$ test.

\section{Results}

The tear lysozyme levels in patients with acute 
Table 1 Tear lysozyme levels in $\mathrm{mg} / \mathrm{ml}$ in healthy subjects, acute adenovirus conjunctivitis, and different stages of conjunctivitis

\begin{tabular}{llll}
\hline & $\begin{array}{l}\text { No. of } \\
\text { subjects }\end{array}$ & Mean $\pm S D$ & Range \\
\hline Healthy subjects & 92 & $1 \cdot 45 \pm 0 \cdot 60$ & $0 \cdot 32-2 \cdot 85$ \\
Conjunctivitis & 98 & $1 \cdot 15 \pm 0 \cdot 50$ & $0 \cdot 30-2 \cdot 44$ \\
$\quad$ Mild & 28 & $1 \cdot 36 \pm 0 \cdot 48$ & $0 \cdot 32-2 \cdot 20$ \\
$\quad$ Moderate & 52 & $1 \cdot 13 \pm 0 \cdot 47$ & $0 \cdot 32-2 \cdot 44$ \\
Severe & 18 & $0 \cdot 90 \pm 0 \cdot 50$ & $0 \cdot 30-1 \cdot 92$ \\
\hline
\end{tabular}

SI conversion: $\mathrm{mg} / \mathrm{ml}=\mathrm{g} / \mathrm{l}$.

Table 2 Tear lysozyme levels in $\mathrm{mg} / \mathrm{ml}$ in the acute phase in viral isolation-positive and viral isolation-negative patients with acute adenovirus conjunctivitis

\begin{tabular}{llll}
\hline & $\begin{array}{l}\text { No. of } \\
\text { subjects }\end{array}$ & Mean $\pm S D$ & Range \\
& & & \\
\hline Isolation-positive & 30 & $1 \cdot 07 \pm 0.49$ & $0 \cdot 32-1.98$ \\
Isolation-negative & 68 & $1 \cdot 19 \pm 0.50$ & $0 \cdot 30-2.44$ \\
\hline
\end{tabular}

SI conversion: $\mathrm{mg} / \mathrm{ml}=\mathrm{g} / \mathrm{l}$.

adenovirus conjunctivitis and healthy controls is given in Table 1 . It was $1.49 \pm 0.69 \mathrm{mg} / \mathrm{ml}$ in males and $1.41 \pm 0.50 \mathrm{mg} / \mathrm{ml}$ in females and the difference in the two sexes was not significant statistically $(p>0 \cdot 80)$. There was a significant decrease when the tear lysozyme level in the acute stage was compared with the level in healthy subjects $(\mathrm{p}<0 \cdot 001)$. (SI conversion: $\mathrm{mg} / \mathrm{ml}=\mathrm{g} / \mathrm{l}$.)

Table 1 also shows tear lysozyme levels in mild $(1.36 \mathrm{mg} / \mathrm{ml})$, moderate $(1.13 \mathrm{mg} / \mathrm{ml})$, and severe $(0.90 \mathrm{mg} / \mathrm{ml})$ types of acute adenovirus conjunctivitis. The tear lysozyme level showed a significant decrease in moderate $(\mathrm{p}<0.001)$ and severe $(\mathrm{p}<0.001)$ types of disease, while its level in the mild type $(p>0.50)$ remained unaltered in comparison with the levels in healthy subjects $(1.45 \mathrm{mg} / \mathrm{ml})$.

The tear lysozyme levels in patients who were viral isolation-positive and viral isolation-negative is given in Table 2. A statistically significant difference was found when the level in healthy subjects $(1.45 \mathrm{mg} / \mathrm{ml})$ was compared with the level in viral isolationpositive patients $(\mathrm{p}<0.01)$ and viral isolationnegative patients, $(p<0 \cdot 01)$. However, there was no statistically significant difference $(p>0.3)$ between the tear lysozyme level in viral isolation-positive patients $(1.07 \mathrm{mg} / \mathrm{ml})$ and viral isolation-negative patients $(1 \cdot 19 \mathrm{mg} / \mathrm{ml})$.

The tear lysozyme levels were determined in 56 patients during the acute and remission stages. During the acute phase the level was $1 \cdot 11 \pm 0 \cdot 50$ $\mathrm{mg} / \mathrm{ml}$ (range 0.30 to $2.20 \mathrm{mg} / \mathrm{ml}$ ), and the level rose to $1.32 \pm 0.44 \mathrm{mg} / \mathrm{ml}$ (range 0.37 to $2.20 \mathrm{mg} / \mathrm{ml}$ ) during remission. There was a statistically significant difference $(p<0.02)$ in the levels in the acute and remission stages. There was no significant difference $(p>0 \cdot 20)$ between the tear lysozyme level in the remission stage and the level in healthy subjects.

\section{Discussion}

The tear lysozyme levels have been measured on the premise that changes in tear protein levels may reflect significant events in acute adenovirus conjunctivitis. Several studies have been reported on the tear lysozyme levels in healthy subjects. ${ }^{21022}$ Low levels have been reported in tears from patients with trachoma $^{12}$ and lepromatous leprosy. ${ }^{13}$ However, tear lysozyme levels have been shown to be unaltered in acute bacterial conjunctivitis," vernal conjunctivitis, " phylectenular keratoconjunctivitis, " chronic irritative conjunctivitis," and nutritional xerosis." Tear lysozyme levels have been reported to be significantly low in patients with herpes simplex virus eye infections."

It has been suggested that a low tear lysozyme level in patients with acute bacterial conjunctivitis is due to excessive tearing. ${ }^{10}$ The low level of tear lysozyme in patients with acute adenovirus conjunctivitis which we observed in this study may be partly explained by the excessive tearing frequently observed in these patients.

There is a correlation between increasing severity of the disease and the reduction in tear lysozyme level, and there is a return to normal lysozyme level during the remission stage. It is therefore likely that the low level of tear lysozyme in patients suffering from adenovirus conjunctivitis observed in the present study was due to infection and not inherent or pre-existent.

\section{References}

1 Copeland JR, Lamberts DW, Holly FJ. Investigation of the accuracy of tear lysozyme determination by the quantiplate method. Invest Ophthalmol Vis Sci 1982; 22: 103-10.

2 Avisar R, Menache R, Shaked P, Rubinstein J, Machtey I, Savir $\mathrm{H}$. Lysozyme content of tears in patients with Sjögren's syndrome and rheumatoid arthritis. Am J Ophthalmol 1979; 87: 148-51.

3 Erickson O. The absence of lysozyme in Sjögren's syndrome. Stanford Med Bull 1955; 13: 292-7.

4 Mackie IA, Seal DV. Quantitative tear lysozyme assay in units of activity per microlitre. BrJ Ophthalmol 1976; 60: 70-4.

5 McEwen W, Kimura SJ. Filter paper electrophoresis of tears. I Lysozyme and its correlation with keratoconjunctivitis sicca. Am J Ophthalmol 1955; 39: 200-5.

6 Velos P, Cherry PMH, Miller D. An improved method for measuring human tear lysozyme concentration. Am J Ophthalmol 1985; 103: 31-3.

7 van Bijsterveld OP. Diagnostic tests in the sicca syndrome. Arch Ophthalmol 1969; 82: 10-4. 
8 Sapse AT, Bonavida B, Stonc W Jr, Scrcarz EE. Human tear lysozyme. III. Preliminary study of lysozyme levels in subjects with smog cye irritation. Am J Ophthalmol 1968; 66: 76-9.

9 Ronen D, Romano A, Smetana O. Lysozyme tear levels in patients with herpes simplex virus eyc infections. Invest Ophthalmol Vis Sci 1977; 16: 850-3.

10 Regan E. The lysozyme content of tears. Am J Ophthalmol 1950; 33: 600-5.

11 Sen DK, Sarin GS. Immunoassay of tear lysozyme in conjunctival diseases. Br J Ophthalmol 1982; 66: 732-5.

12 Sen DK, Sarin GS. Tear lysozyme in patients with trachoma. Indian J Ophthalmol 1982; 30: 139-41.

13 Sen DK, Sarin GS. Tear lysozyme in lepromatous leprosy. Int J Lepr 1982; 50: 322-4.

14 Avisar R, Menache R, Shaked P, Rubinstein J, Machtey I. Lysozyme content of tears in some external eye infections. Am J Ophthalmol 1981; 92: 555-8.

15 Gupta AK, Sarin GS, Mathur S. Tear lysozyme concentration in corneal ulcer. Afro-Asian J Ophthalmol 1982; 1;29-31.

16 Watson RR, Reyes MA, McMurray DN. Influence of malnutri- tion on the concentration of $\operatorname{IgA}$, lysozyme, amylase and aminopeptidase in childrens' tears. Proc Soc Exp Biol Med 1978; 157: 215-9.

17 Gupta AK, Sarin GS. Serum and tear immunoglobulin levels in acute adenovirus conjunctivitis. $\mathrm{Br} \mathrm{J}$ Ophthalmol 1983; 67: 195-8.

18 Gupta AK, Sarin GS. Serum complement component depression during acute adenovirus conjunctivitis. BrJ Ophthalmol 1984; 68: 350-2.

19 Gupta AK, Prasad AK. Epidemic actue conjunctivitis in Delhi (1981): a virological study. Afro-Asian J Ophthalmol 1982; 1: $62-5$.

20 Sen DK, Sarin GS, Mani K, Saha K. Immunoglobulins in tears of normal Indian people. $\mathrm{Br} J$ Ophthalmol 1976; 60: 302-4.

21 Mancini G, Carbonara AO, Heremans JF. Immunochemical quantitation of antigens by single radial immunodiffusion technique. Int J Immunochem 1965; 2: 235-54.

22 Sen DK, Sarin GS. Immunoassay of human tear lysozyme. Am J Ophthalmol 1980; 90: 715-8.

Accepted for publication 18 October 1985. 